\title{
Examining the Agreement Object as Good Deeds from the Consequentialism and Deontology Perspective
}

\author{
Taufiq El Rahman ${ }^{1}$ \\ ${ }^{1}$ Faculty of Law, Universitas Gadjah Mada \\ Corresponding author's email: perdata_bw@yahoo.com
}

\begin{tabular}{l}
\hline Article Information \\
\hline Submitted : August 02, 2021 \\
Reviewed : September 10, 2021 \\
Revised : November, 242021 \\
Accepted : December 13, 2021 \\
Keywords: \\
the agreement object, good deeds, \\
legal philosophy perspective \\
DoI: $10.20961 /$ yustisia. \\
v10i3.56519
\end{tabular}

Abstract
This study aimed to analyze the agreement object as good deeds
from the legal philosophy perspective. Postulated to legal posi-
tivism, this rejects the deviation of the agreement on the good
deed of transplanting organs or body tissues. The results com-
piled using normative legal research methods described the flow
of consequentialism and deontology. The flow states that kidney
transplant procedures conducted voluntarily based on human-
ity have benefited recipients and donors. Therefore, they increase
the happiness level of both parties without leaving the concept of
Kantian moral ethics.

\section{Introduction}

An agreement or contract is a juridical instrument used to protect the parties' interests in legal action. Agreements vary in form, substance, and the parties involved, meaning that they have principles. These principles ensure each stage in the agreement does not violate the legislation provisions, justify every cause, and crash into community morality and propriety. The parties often select an underhand agreement without involving a notary. This agreement is relatively less costly and meets its validity requirements regulated in Article 1320 of the Civil Code. However, the agreement sometimes requires a notary to make a notarial deed. As a noble profession (nobile officium), the notary's movements and behavior should be based on applicable legal norms and ethics.

Related to the notary's role and function, this aimed to examine the agreement object made by the parties before a notary. Although the study problem is commonplace, it becomes interesting when the agreement object to be analyzed is essentially a gray 
area. The agreement object made before a notary is a derivative of the kidney transplant performed by the parties. Specifically, the agreement object ${ }^{1}$ is a promise of a good deed from one party to another. For instance, the donor would be given medical expenses during surgery until he is declared cured. In this case, each party would not file a lawsuit when the future organ or body tissue transplantation affects the parties' health conditions. This agreement object is the realization of a good deed from the recipient to the organ or body tissue donor made before a notary. Good deeds are limited only when the donor and recipient are alive. When one party dies, the realization of achievements according to article 1234 of the Civil Code would be another matter. Philosophically, good deeds embody inner, moral, and ethical attitudes to act autonomously, independently, and voluntarily. In this case, one person's actions do not violate the law based on morality and justice for individuals and the universe (Mayo, 1986).

A review of several publications on organ or body tissue transplantation shows that the existing publications only discuss descriptively with no correlation with legal schools. For instance, Abhimantara publications emphasized that body organs or tissues are objects that cannot be commercialized based on legislation (Ida B. Abhimantara, 2018). Furthermore, a transplant agreement based on personal will does not violate the law, but it violates humanity and requires a more comprehensive regulation of legal norms (Aristantie et al., n.d.). According to Lembong et al. (n.d.), a non-penalty policy is needed to avoid legal irregularities in organ or body tissue trade transactions.

The available legal norms indicate that organ or body tissue transplantation has been regulated internationally and domestically. Indonesia has ratified the Palermo Protocol through Law Number 14 of 2009 concerning Ratification of the Protocol to Prevent, React, and Punish Human Trafficking, especially Women and Children, Supplementing the United Nations Convention Against Transnational Organized Crime. This ratification was strengthened by the issuance of Law Number 21 of 2007 concerning the Eradication of the Human Trafficking Crime. The law emphasized that organ or body tissue transplantation under the pretext, motive or commercial reasons is prohibited and unlawful. This affirmation is also seen in Law Number 36 of 2009 concerning Health, where trade in organs or body tissues may not be transacted with any argument.

The prohibition of trading in organs or body tissues has shifted with the dynamics and demands of development in the health sector. The amendment was marked by the issuance of Government Regulation Number 53 of 2021 concerning the Transplantation of Body Organs and Tissues. This Government Regulation allows for organ or tissue transplantation with rigid administrative and medical operational limitations. The Regulation stipulates that transplantation could only be performed voluntarily, for humanitarian purposes, and prohibited from being traded under any pretext. The

1 The notarial deed containing the good deeds as legal material in this research was deliberately not published because it relates to the confidentiality of the agreement documents made by notaries in several areas of Central Java and Yogyakarta. However, to maintain the objectivity of the research, the entire document has been documented. 
Government through Article 24 paragraph (1) (d) Regulation of the Health Minister Number 38 of 2016 concerning Organ Transplantation confirms that donor recipients must submit a written statement not to buy body organs of the prospective donor or make a special agreement with them. The agreement should be submitted as a notarial deed or written statement legalized by a notary to avoid legal smuggling in transplanting organs or body tissues.

This study focuses on preparing an authentic deed before a notary concerning organ or tissue transplant. The answer to this legal issue is illustrated when the case is examined from a positivist perspective. According to legal positivism, the parties' actions to agree to a notary are prohibited from contradicting or colliding with legal norms. Violations of legal norms would result in strict sanctions, and the formulated agreement may be nullified (Austin, 1862; Singer, 2005). However, the taboos of legal positivism are still practiced by notaries. In pre-study interviews, several notaries 2 stated that the agreement object formulated by the parties is separate from the main organ or tissue transplant agreement. Furthermore, the notaries stated that the agreement object formulation is supported by legal schools. Therefore, this study aimed to analyze the agreement object from Mills's consequentialism and Kant's deontology.

\section{Methods}

This study was written using a normative legal method with case approach philosophical approaches. Data were obtained from secondary legal sources using content analysis, structured interviews, and literature review. The conclusion was obtained using the legal syllogism and hermeneutics method.

\section{THE agreement Object is 'good deed' from consequentialism and deontological Perspectives}

\section{A. Mill's consequentialism view of 'good deeds' in an agreement}

Utilitarianism is part of the consequentialism theory family with a view that a good or bad action leads to its consequences, and happiness is a major goal to be achieved by every human being. Many utilitarianism theories classify humans' good and bad actions in performing their roles as social beings. The philosophical study of a good deed in John Stuart Mill's thinking is a refinement of the utilitarianism theory developed by Jeremy Bentham. According to the two utilitarianism theories, it is essential to see the impact of action as a logical consequence that qualifies the act as good or bad.

Mill's book entitled Utilitarianism sparks a philosophical discussion of the categories that determine the goodness of human action through basic questions.

2 The interview was conducted in a structured manner, where the name and the work area of the notary were deliberately kept secret to maintain privacy, but all the evidence was stored. 
Logical analysis is needed to help prove the good deeds of medical science that contribute to providing health for humans. Moreover, the analysis should show that music is a good thing when enjoyed by many listeners. In this case, Mill agrees that not all good deeds could be proven, though this does not mean that it is based on unclear standards. Assessment of the good and bad action should be based on logical and rational thinking accompanied by evidence.

Mill used a logical basis to explain the standards to determine the good and bad of action. Therefore, it is necessary to understand the different concepts of happiness, benefit, and pleasure (John Stuart Mill, 1863). According to Mill, benefits and pleasures are different things, and the measure of happiness is relative. One person's standard of happiness with another cannot be based on the same measure (O'Connor, 1997). In this case, fulfilling actions that bring happiness is difficult for people with a high living standard. They have everything and perceive the world as a condition full of imperfections, unlike people with a lower living standard. In this context, a lower living standard applies to the poor and those with a simplicity spirit, where something small makes them happy.

Another analogy used by Mill to describe different standards of goodness, contentment, and happiness is expressed through the parable of Socrates and the man of no breadth. Socrates would find it more difficult to be satisfied with what he already knew. However, people with a narrow view would be easily satisfied because they do not think of certain parts. In this analogy, it would be better to be Socrates that are not easily satisfied with the knowledge obtained, though this could also mean that more effort should be made to achieve happiness. This is different from the analogy used to describe the happiness obtained based on human living standards.

The utilitarian view stated that happiness is part of a benefit (Edwards, 1986). People only achieve their goals when they consistently uphold the nobility of character based on goodness. In this theory, the basic principles a person adheres to are inseparable from an ethic adopted as a moral value and principles appropriate with the social nature of humans. By adhering to the principle of achieving happiness, people would strive to distance themselves from pain to obtain the quantity and quality of pleasure (Michael Robertson \& Garry Walter, 2017). As explained in Mill's analogy, the standard of quantity and quality of striving for happiness depends on the people's experiences. Based on selfawareness and observations to make comparisons, everyone would know the efforts needed to achieve happiness.

The good deeds to achieve happiness should be morally appropriate with the perception built on the applied rules to regulate human actions. Therefore, the actions needed to achieve happiness could still be accounted for individually 
and all living beings. According to Mill, happiness is the only standard of morality because everyone wants a happy life. As proof, people desire to achieve something that fits their happiness definition. This means that good deeds lead to happiness, while bad actions result in unhappiness.

The concept of happiness is simply indicated by the presence of pleasure and the absence of pain (Escamilla, 2008). However, no one type of happiness should be owned by everyone, and its attainment is not the end of a rational act or a moral value (Hamudy, 2019). The morality of utilitarianism recognizes the great power of a sacrifice to achieve happiness. In this case, people could do good deeds by sacrificing something that means a lot for the happiness of others. However, Mill stated that sacrifices without increasing happiness are futile. The understanding of the Utilitarianism principle by Mill has provided the basis to examine an action as a good deed (Marseille \& Kahn, 2019).

This study aimed to examine the possibility of the agreement object of an organ transplant to fulfill the elements of good deeds expressed by Mill in the theory of Utilitarianism. An agreement contains parts that should be fulfilled as a condition for validity. This section comprises essentialia, naturalia, and accidentalia, which contain the parties' achievements (Muhamad Noor, 2015). Furthermore, the agreement is valid and lawful when it does not violate legal provisions (Hartana, 2016). In this context, good deeds are important as an object in an organ transplant agreement. This cannot be ignored because organ transplantation could be a form of legal smuggling from trade transactions. Therefore, it is necessary to analyze whether an object agreed as a reward for the organ transplant process meets the criteria of good deeds and not for the sale of kidneys. The basic spirit of the utilitarianism principle and the making of an agreement aims to benefit the parties involved.

The principle of utilitarianism explains that the benefits received from a good deed are true happiness as the main goal of every human being. The main purpose of making an agreement is to fulfill its object and the parties' achievements. Therefore, the parties have agreed to reciprocate good deeds to bring benefits and happiness in line with the agreement. Based on the arising engagement, an agreement is considered valid as a special law for the parties that bind themselves and reach a consensus (Harry Purwanto, 2009).

In this discussion, the agreement that applies as law for parties in the organ transplant process has been legally contained and made before a notary. The agreement explained that the second party had donated his kidney to the first party. Furthermore, the donor covered all costs, including pre-operative, operating, and post-operative, until the doctor handling the transplant states that the second party is in good health. These conditions necessitate a review of the organ transplantation cost as the agreement object. The Law on Health 
regulated that organs or body tissues cannot be traded with any argument. Moreover, this agreement is unclear and a possible avenue for covert organ trading practices. Therefore, the utilitarianism theory is chosen to prove whether the cost fulfillment by the first party as the organ recipient is a good deed or a camouflage in trading organs.

Regarding the study on utilitarianism, the specificity of an agreement that only binds the parties involved is consistent with the interpretation of the maxim good deeds (Edi Hudiata, 2014). Kant's theory holds that everyone's happiness standards are not the same as others. Therefore, an action categorized as a good deed in an agreement should meet the expectations of the parties involved. As an agreement object, good deeds are the benefits for each party. These benefits are the desires to be fulfilled as a right for the parties to achieve happiness. From this case, Kant emphasized that benefits and advantages are different things. For instance, a profit derived from a trade transaction cannot be a good deed. However, the benefits derived from an action that brings happiness manifest a good deed (John Stuart Mill, 1863).

The utilitarianism theory interprets good deeds by applying the principles in an agreement (Devina Yuanitasari \& Hazar Kusmayanti, 2020). In this case, the principle of consensualism results in an agreement outlined in parts. The achievements mutually agreed upon are the results of the rational thoughts of each party involved. These conditions contain the wishes to be carried out to make the agreement. In this context, the agreed good deed is a wish that brings happiness to the parties upon fulfilling the achievement.

The principle of freedom of contract in making agreements allows the parties to choose according to their respective preferences. It includes the freedom to decide to make an agreement, the party to agree with, its form, content, and terms. This allows each individual to determine the best path to achieve the desired happiness (Rahmani Timorita Yulianti, 2008). Mill's utilitarianism theory states that when someone decides to agree with another party, fulfilling the good deeds agreed upon should lead to true happiness.

Third, the maxim good deeds in the agreement is a special standard applicable only to certain covenant contexts based on the personality principle (John Stuart Mill, 1863). As Mill has analogized using the story of a humble and intelligent person, everyone has a specific standard of happiness and the effort required for its achievement. The standard cannot be applied generally because it is strongly influenced by personal preferences. This is in line with the principle of personality in a covenant. The benefits obtained for achieving happiness by fulfilling the agreement object good deeds only apply to the parties involved. In line with this, Article 1315 of the Criminal Code explicitly states that the parties 
cannot include third persons outside the agreement (Siti Malikhatun Badriyah, 2012).

Mill's standard logic means that the good deeds used to achieve the parties' happiness may not meet the expectations of those not involved in formulating the agreement. This should not be binding on parties outside the agreement, except those excluded through Articles 1317 and 1318 of the Criminal Code. Furthermore, Mill emphasized that even the greatest sacrifice is not a good deed when it cannot increase the happiness of the person being treated.

An agreement must be based on good faith as a manifestation of honest thinking to achieve a goal. In this case, there is a responsibility to fulfill duties and obligations with reasonable transaction standards without fraudulent intentions (Niru Anita Sinaga \& Nurlely Darwis, 2015). Therefore, the good deeds as the agreement object must be made based on social, moral values. According to Mill's logic, good deeds must be morally justifiable for covenant makers and all living beings.

Applying good deeds as an object in an organ transplant agreement ratified using a notary deed based on the utilitarianism theory has clear limitations. In line with the agreement-making principles, the achievement and the agreement are realized by the parties as a common goal based on good faith. In this case, the good deeds agreed to are reciprocal actions for each party. The second party as a donor has performed a good deed by giving organs to the first party. Similarly, the first party as the recipient promised to bear the donor's examination, action, and recovery cost as a good deed.

The principle of utilitarianism prioritizes benefits to achieving everyone's happiness. It means that organ donation by the second party benefits the first party by restoring their health. This is expected by the first party to create happiness for himself and from the transplant procedure, meaning that the second party makes certain sacrifices as a donor. From a utilitarian perspective, the sacrifices made by the second party to donate organs to the first party manifest good deeds.

In explaining the utilitarianism theory, Mill stated that good deeds are performed through a sacrifice by someone for others to achieve happiness (John Stuart Mill, 1863). In this case, the donor has sacrificed a healthy part of himself to provide health to people expecting him to be happy. Therefore, this increases the happiness of the donor-recipient in line with the basic principles of the utilitarianism theory.

The first party guarantees the necessary costs until the doctor declares the donor healthy in return for the organ donation process. The guarantee to fulfill the costs used until the donor recovers his health is a desire agreed upon by both parties. The restoration of the donor's health after organ transplantation is 
expected. In this case, the object of the agreement is said to meet the requirements as a good deed based on the utilitarian theory. Donors that voluntarily sacrifice their health feel happy providing health for themselves and donor recipients.

The quality standard of happiness in the organ transplant process is measured by assessing their desires. This is in line with Mill's statement that desire is a path to happiness. People's preferences are seen when two factors make them happy, where one factor is superior and determines the quality of happiness (John Stuart Mill, 1863). The organ transplant agreement contains a desire from the first party to receive a kidney to regain health. Similarly, the second party desires to fulfill all costs arising from the kidney transplant process. Therefore, the first party has money to make him healthy again, while the second party has a healthy kidney for transplantation.

Health and money become the object of happiness from the first party. However, he prioritizes health to willingly sacrifice his money when there is a healthy kidney to be transplanted. The money is used to cover the transplant cost expected to bring him back to health. Therefore, he hopes to obtain health as his goal when the sacrifice is made through transplant costs for himself and donors. Similarly, the second party sacrificed his healthy kidney as social care for others to achieve happiness.

The standard that the second party's action is a sacrifice included in good deeds is seen from the agreed clause. In this case, the second party is guaranteed fulfillment of the transplant cost until declared healthy. He does not benefit materially because this depends on the buying and selling process results. When the benefit is not what the second party expects, it is achieved from the action. As stated in the agreement, each party knows, understands, agrees consciously, healthily, and is responsible for the risks and consequences of the kidney transplant process. This means that both parties have understood the action's benefits and side effects and voluntarily carried out a kidney transplant.

The first party's benefit from a transplant action becomes the second party's priority desire as a substitute for the unwanted benefit preference. The second party made a sacrifice by delivering his healthy kidney to the first party. This action is expected to be the path desired by the first party to achieve happiness. Based on these considerations, the second party's sacrifice is a sign of good deeds that have fulfilled the elements that increase the first party's happiness (John Stuart Mill, 1863).

From the perspective of utilitarianism, the good deeds agreed before the notary remains in the legal corridor. In contrast, organs and body tissues are only transplanted voluntarily, for humanitarian purposes, and prohibited from being traded under any pretext. An agreement made legally before a notary contains the principle of freedom binding the parties and is implemented based 
on the donor's voluntary desire. The donor expects the recipient to meet the transplant process and health restoration costs as a reciprocal agreement. This shows that the donor receives no remuneration or benefits as organ replacement materials he provides. Therefore, the action contains human moral values and is not a trade transaction with material benefits from the seller or donor.

The organ transplant procedure is a form of good faith within the agreement made by the parties. Therefore, the good deeds in the organ (kidney) transplant agreement fulfill the elements of a legal agreement in line with Mill's utilitarian theory. This analysis shows clear boundaries when discussing good deeds in morally and socially accountable organ transplant practices that do not violate the applicable laws in Indonesia, where the agreement was made.

\section{b. Kant's deontology as the basis for maxim's interpretation of 'good deeds' in covenants}

Explaining the deontic logic concept is closely related to using mathematical formulas in describing the logical relationship between the premises used. However, this is not the case with the deontic logic postulated by Immanuel Kant, which rejects mathematical formulas to describe a moral and human principle (Kant et al., 2012). According to Kant, the discussion of basic principles based on personal logical thinking cannot be translated into algorithms. Every human being is rational, acting based on rational thought, implying 'ends-in-ourselves' (Rachmawati et al., 2013). Therefore, it is appropriate for everyone to select a different goal.

The rational choice used by everyone to determine steps in solving their problems is a right not to be violated by others. Differences in views and ways to solve problems are natural because everyone has a different perspective and a logical basis. This choice is closely related to moral values as a guide to social behavior. In this case, Kant emphasizes that people only need to search within themselves concerning the problem's background and their resources as a solution. The philosophical study conducted through these basic questions results in free choices as an individual in solving the problems.

It is necessary to analyze the general social truth standards regarding the individual's freedom to act rationally. This means that a person's moral action must come from rational thinking and social, moral values. Fulfilling these standards is a prerequisite to carrying out Kant's obligation principle that tells what to do without analyzing the content of moral values in action.

Kant described the obligation principle as an individual awareness of what has become his obligation (Kant et al., 2012). In this case, a person consciously fulfilling his responsibility without coercion manifests social, moral values. Furthermore, this principle emphasizes that every action taken to fulfill responsibility is not aimed for personal gain (Imo M. Obot, 2014). In using rationality to choose the best action, 
the aspects considered for the choice do not have to come from personal experience. Kant asserted that everyone has this knowledge, making rational minds adopt moral values without prior analysis.

The character of universality in a law contains orders to be obeyed, and everyone has an indirect obligation and responsibility to comply with these rules. As with moral values, legal provisions are an order that must be obeyed, regardless of the subject's motivation in implementing the order. According to Kant, this is called law and is an obligation (Cristian Dimitriu, 2013). He introduced two types of commands, Categorical Imperative (CI) and Hypothetical Imperative (HI), to understand more about the basic nature of moral principles (Thriyana, 2016).

Hypothetical Imperative is contextual command based on the prevailing conditions, and it adjusts when the goals to be achieved change. Kant gave an example a child participates in different talent development activities depending on their objectives. Moreover, Kant translated the Categorical Imperative as absolute orders with basic moral values from the Kantian Ethical model. As a result, Categorical Imperatives were later called the supreme principle of morality.

Kantian basic moral ethics are based on goodwill morally justifiable as a practice from the Categorical Imperative (Agbude et al., 2015). According to Kant, every action must be executed with good intentions independent of any conditions and benevolent values. A person consciously performing his duties and responsibilities without considering future rewards has acted with good intentions. Therefore, every human being has the freedom to act based on personal self-awareness, known as self-legislating.

Kant stated that a rational action could be moral or immoral (Albertzart, 2019). In this case, a person consciously performing his duties responsibly without coercion and not expecting a reward commits a moral act. Therefore, a moral action is in line with general social values. In contrast, a person acting to fulfill an obligation has no moral value. Furthermore, a person whose actions violate general rules commits an immoral act.

Kant's categorical imperative views that the maxim used to formulate an order or rule should be universal and sensitive to human values (Ehrlich, 1982). This provision emphasized the importance of formulating a generally applicable policy that does not contradict the truth. This means that Kant's view of a good rule does not focus on its consequences but the importance of the true value it brings. Therefore, the right actions are in line with the legally binding law maxims, where the truth and conformity of actions with the rule of law are inseparable.

Kant added that formulating human values requires everyone to respect the choices of others due to differences in each person's rational choices, implying 'endsin-ourselves.' The moral-ethical standards introduced by Kant do not allow a person to violate the autonomous rights of others in making decisions. Furthermore, the 
essence of human values ensures that everyone is treated properly, not as inanimate objects only used and thrown away when no longer commercially profitable (Jacquette, 1991).

Based on Kant's deontic logic, good deeds are agreement objects that emphasize the importance of freedom in determining the category standards without violating the Kantian moral ethics. In this case, the agreement to formulate achievements allows the parties to fulfill their obligations. Several aspects must be met to qualify the good deeds in the agreement as a form of the categorical moral imperative. One major condition forming the spirit of Kant's deontic logic is the fulfillment of a general standard of truth.

In line with the first principle in the agreement-making procedure, an agreement must be based on the parties' consensualism. This means that an agreement is made to design essentialia, naturalia, and accidentalia. Kant highlighted the moral, ethical standards that must be met in formulating the agreed good deeds as an agreement object. In this regard, good deeds must be formulated to contain general truth values and performed with good intentions. This action is independent of any conditions and brings benevolent values for the parties involved in the agreement.

Kant recognized the concept of self-legislation and rational thought owned by every individual, making humans act autonomously without violating the autonomy of others. This moral, ethical value must be considered in carrying out the principle of freedom in contracting. The freedom to choose to make an agreement, the party to agree with, and the agreement's content, form, and terms must remain subject to the rule of law, moral values, and the general truth. This concept automatically leads the parties to perform their respective obligatory acts.

Fulfilling achievement as an obligation requires the parties' awareness of their duties and responsibilities to act according to the agreement. Good deeds should then be interpreted as a categorical imperative as an agreement object. The principle of personality in an agreement is closely related to the categorical imperative concept that helps define good deeds. Therefore, the object of the agreement must be fulfilled to feel the benefits agreed by the parties. Moreover, the universality concept in the categorical imperative requires compliance from all parties bound by these rules. The basic principle of humanity must be included in the concept of good deeds translated as a categorical imperative. Therefore, the agreed good deeds must manifest the supreme principle of morality.

The principle of good faith in an agreement manifests Kant's concept. In this case, the good deeds agreed as agreement objects are moral actions obtained from the rational minds of the parties involved. The limits in interpreting good deeds automatically adopt moral values without prior analysis. Furthermore, Kantian moral ethics ensure that every action must be based on goodwill and morally justifiable. The good deeds in the agreement must comprise actions based on a 
person's awareness to perform his duties and responsibilities by considering moral and human values and not the rewards.

The theory of deontic logic put forward by Kant to interpret a good deed as an object in the agreement shows that the organ transplant has fulfilled the elements of good deeds. As a human being with a social spirit based on moral ethics, Kant emphasized the importance of accountable actions taken based on good intentions. Therefore, the agreement made by the donor and recipient during legal organ transplantation before a notary is a voluntary action based on each party's rational thinking. Furthermore, the principle of freedom in making a contract indicates the parties' willingness to participate in the action.

Kant's concept is the basis of good faith agreed as good deeds in the agreement. Donors with good intentions to provide organs receive the recipients' guarantees to meet all costs until they are declared healthy again by the doctor organ transplantation. The agreement is independent thinking or self-legislation in line with their personal preferences (ends-in-ourselves). This is evidenced by a clause in the agreement stating that the parties have realized the impact of the organ transplant and would not file any claims in the future.

This action is a form of a humanitarian principle and moral responsibility to help others because the donor receives no material reward. Therefore, the promised good deeds as the object of the organ transplant agreement is a categorical imperative applicable to both parties. Fulfilling achievements as a responsibility to exercise the principle of obligation is a good deed carried out by the parties. This is inseparable from the obligation as an action based on a person's awareness to perform his duties and responsibilities based on moral and human values without considering the rewards for his actions.

The good deeds agreed as the object of the organ transplant agreement is a legally valid act. However, it is motivated by the kidney surrender in organ transplantation. This is possible because Kant's deontic logic theory states that the agreed good deeds are consistent with the principles of moral ethics in a categorical imperative. In this case, the donor's willingness to carry out a kidney transplant without asking for material compensation in return is an act of humanity. Therefore, helping those in need is in line with the general principles of social truth and morality as the spirit of a categorical imperative in deontic logic.

\section{Conclusion}

Postulated to the view of legal positivism, every authentic deed before a notary requires compliance with existing positive legal norms. As a result, the gray area in organ and tissue transplantation is difficult to reach because of the rigidity of this flow. Mill's legal school of utilitarianism justifies the object of the agreement as a good deed. The good deeds that became the agreement have been adjusted to the 
achievements expected based on personal preferences without violating the legal principles regarding organ transplantation in Indonesia. Furthermore, the kidney transplant procedure performed voluntarily based on humanity benefits the donor and the recipient. It increases the happiness of both parties based on Kantian moral ethics. This justification is supported by Kant's theory of deontic logic. In this case, the good deeds contained in the agreement are a categorical imperative containing the values of the supreme principle of morality and morally responsible for everyone. Therefore, the principle of humanity that underlies these actions is an obligation of both parties. It results from independent thinking or self-legislation in line with their personal preferences (ends-in-ourselves) by adhering to a priori considerations.

\section{Acknowledgments}

This article results from a study using the HPJN scheme, Faculty of Law, Gadjah Mada University, Fiscal Year 2021.

\section{Bibliography:}

\section{Book}

Austin, J. (1862). The Province of Jurisprudence Determined. https:/ / www.cambridge.org/ core/books/austin-the-province-of-jurisprudence-determined/930093B7F0872F4 CE799C6A5326DE724

John Stuart Mill. (1863). Utilitarianism. Batoche Books Limited.

Kant, I., Gregor, M. J., \& Timmermann, J. (2012). Groundwork of the metaphysics of morals (Revised edition). Cambridge University Press.

Mayo, B. (1986). The Philosophy of Right and Wrong. Routledge.

Rachmawati, D. U. C., Hasani, I., Setara Institute (Jakarta, I., \& Pustaka Masyarakat Setara (Publisher) (Eds.). (2013). Masa depan Mahkamah Konstitusi RI: Naskah konferensi Mahkamah Konstitusi dan pemajuan hak konstitusional warga. Pustaka Masyarakat Setara.

Singer, M. (2005). The Legacy of Positivism. https://www.amazon.com/LegacyPositivism-Michael-Singer/dp/1403994021

\section{Journal}

Agbude, G. A., Ogunwede, J. K., Godwyns-Agbude, J., Wogu, I. P. A., \& Nchekwube, E.O. (2015). Kant's Categorical Imperative and the "Business" of Profit Maximization: The Quest for Service Paradigm. Technology and Investment, 06(01), 1-11. https:/ / doi.org/10.4236/ti.2015.61001 
Albertzart, M. (2019). A Kantian solution to the problem of imperceptible differences. European Journal of Philosophy, 27(4), 837-851. https:/ / doi.org/10.1111/ejop.12456

Aristantie, Suhariningsih, \& Yuliati. (n.d.). PERJANJIAN ANTARA PENDONOR DAN PASIEN YANG MEMBUTUHKAN “GINJAL" UNTUK TRANSPLANTASI (ANALISIS PASAL 64 UNDANG-UNDANG REPUBLIK INDONESIA NO 36 TAHUN 2009 TENTANG KESEHATAN). 14.

Austin, J. (1862). The Province of Jurisprudence Determined. https:/ / www.cambridge.org/ core/books/austin-the-province-of-jurisprudence-determined/930093B7F0872F4 CE799C6A5326DE724

Cristian Dimitriu. (2013). The Practical Interpretation of the Categorical Imperative: A Defense. Ideas Y Valores, LVII(151), 105-113.

Devina Yuanitasari \& Hazar Kusmayanti. (2020). Pengembangan Hukum Perjanjian dalam Pelaksanaan Asas Itikad Baik pada Tahap Pra Kontraktual. Acta Diurnal, $3(2)$.

Edi Hudiata. (2014). Asas Kepastian Hukum dan Asas Kebebasan Berkontrak sebagai Pertimbangan Utama dalam Penyelesaian Sengketa Perbankan Syariah (Kajian Yuridis Putusan MK Nomor 93/PUU-X/2012). Jurnal Hukum Dan Peradilan, 3(1).

Edwards, R. B. (1986). The principle of utility and Mill's minimizing utilitarianism. The Journal of Value Inquiry, 20(2), 125-136. https:/ / doi.org/10.1007/ BF00144539

Ehrlich, G. E. (1982). Kant, Sartre, and the Categorical Imperative. JAMA: The Journal of the American Medical Association, 247(11), 1566. https://doi.org/10.1001/ jama.1982.03320360018017

Escamilla, M. (2008). Rights and Utilitarianism. John Stuart Mill's Role in its history. Revue d'études Benthamiennes, 4. https://doi.org/10.4000/etudes-benthamiennes.192

Hamudy, N. (2019). Evictions in Jakarta from the View of Utilitarianism. Jurnal Bina Praja, 75-86. https://doi.org/10.21787/jbp.11.2019.75-86

Harry Purwanto. (2009). Keberadaan Asas Pacta Sunt Servanda dalam Perjanjian Internasional. Mimbar Hukum, 21(1).

Hartana. (2016). Hukum Perjanjian (dalam Perspektif Perjanjian Karya Pengusahaan Pertambangan Batu Bara). Jurnal Komunikasi Hukum, 2(2).

IDA BAGUS ABHIMANTARA, S. H. (2018). KARAKTERISTIK PERJANJIAN TRANSPLANTASI ORGAN TUBUH MANUSIA DI INDONESIA [Thesis, Universitas Airlangga]. http://lib.unair.ac.id

Imo M. Obot. (2014). Kant's Categorical Imperative as a Base for Philosophy of Social Studies Moral Education in Nigeria. Journal of Education and Practice, 5(9). 
Jacquette, D. (1991). Moral dilemmas, disjunctive obligations, and Kant's principle that ought to imply can. Synthese, 88(1), 43-55. https:// doi.org/10.1007/BF00540092

John Stuart Mill. (1863). Utilitarianism. Batoche Books Limited.

Kant, I., Gregor, M. J., \& Timmermann, J. (2012). Groundwork of the metaphysics of morals (Revised edition). Cambridge University Press.

Lembong, R. R., Sepang, M., \& Mandagi, R. A. (n.d.). PROSPEK FORMULASI HUKUM PIDANA DALAM PELARANGAN JUAL BELI ORGAN TUBUH MANUSIA UNTUK KESEHATAN DEMI KELANGSUNGAN HIDUP. 6, 11.

Marseille, E., \& Kahn, J. G. (2019). Utilitarianism and the ethical foundations of costeffectiveness analysis in resource allocation for global health. Philosophy, Ethics, and Humanities in Medicine, 14(1), 5. https:/ / doi.org/10.1186/s13010-019-0074-7

Michael Robertson \& Garry Walter. (2017). A Critical Reflection on Utilitarianism as the Basis for Psychiatric Ethics. Journal of Ethics in Mental Health, 2(1).

Muhamad Noor. (2015). Penerapan Prinsip- Prinsip Hukum Perikatan dalam Pembuatan Kontrak. Jurnal Pemikiran Hukum Islam, XIV(1).

Niru Anita Sinaga \& Nurlely Darwis. (2015). Wanprestasi dan Akibatnya dalam Pelaksanaan Perjanjian. Jurnal Mitra Manjemen, 7(2).

O'Connor, M. (1997). John Stuart Mill's utilitarianism and the social ethics of sustainable development. The European Journal of the History of Economic Thought, 4(3), 478-506. https:// doi.org/10.1080/10427719700000063

Rachmawati, D. U. C., Hasani, I., Setara Institute (Jakarta, I., \& Pustaka Masyarakat Setara (Publisher) (Eds.). (2013). Masa depan Mahkamah Konstitusi RI: Naskah konferensi Mahkamah Konstitusi dan pemajuan hak konstitusional warga. Pustaka Masyarakat Setara.

Rahmani Timorita Yulianti. (2008). Asas-Asas Perjanjian (Akad) dalam Hukum Kontrak Syari' ah. Jurnal Ekonomi Islam, II(1).

Singer, M. (2005). The Legacy of Positivism. https://www.amazon.com/LegacyPositivism-Michael-Singer/dp/1403994021

Siti Malikhatun Badriyah. (2012). Pemuliaan (Breeding) Asas- Asas Hukum Perjanjian dalam Perjanjian Leasing di Indonesia. Jurnal Yustisia, 1(2).

Thriyana, D. (2016). Categorical Imperative Immanuel Kant sebagai Landasan Filosofis Pelaksanaan Putusan Arbitrase. PADJADJARAN Jurnal Ilmu Hukum (Journal of Law), 3(1), 83-96. https:/ / doi.org/10.22304/pjih.v3n1.a5 